\title{
PENGARUH PENGELUARAN PEMERINTAH TERHADAP KESEMPATAN KERJA MELALUI INVESTASI DAN DAMPAKNYA PADA KAWASAN TIMUR DAN BARAT INDONESIA
}

\author{
Matius Irsan Kasau', Rahmat Laan² \\ ${ }^{1}$ Dosen Kopertis Wilayah IX Sulawesi dpk pada STMIK Dipanegara Makassar, \\ ${ }^{2}$ Dosen Tetap Universitas Muhammadiah Kupang Nusa Tenggara Timur. \\ e-mails: matius.irsan@gmail.com,rahmatlaan@yahoo.co.id.
}

\begin{abstract}
ABSTRAK
Indonesia terdiri atas 34 provinsi dengan sentuhan pembangunan ekonomi, khususnya kesempatan kerja tidak merata pada seluruh wilayahnya. Menurut teori kausalitas atau teori dependensi, dapat diduga faktor-faktor ekonomi kunci dan utama seperti pengeluaran pemerintah dan investasi tidak memberikan pengaruh dan dampak yang merata terhadap pertumbuhan kesempatan kerja pada Kawasan Timur Indonesia (KTI) dan Kawasan Barat Indonesia (KBI).

Penelitian ini bertujuan untuk menganalisis pengaruh Pengeluaran Pemerintah dan Investasi terhadap Kesempatan Kerja di KTI dan KBI baik langsung, tidak langsung maupun pengaruh secara total pada kedua wilayah. Data yang digunakan adalah data sekunder, kuantitatif berbentuk panel data dari 34 Provinsi periode tahun 2007 hingga tahun 2013 yang diperoleh dari BPS (Badan Pusat Statistik) dengan SEM (Structural Equation Modeling) dan software AMOS Versi 21.0 sebagai alat analisis.

Hasil Penelitian menunjukkan bahwa Pengeluaran Pemerintah berpengaruh positif dan signifikan terhadap Investasi dan Kesempatan Kerja baik langsung, tidak langsung maupun secara total. Demikian juga halnya pengaruh Investasi terhadap kesempatan Kerja baik di KTI maupun di KBI. Namun pengaruh di KTI lebih kecil dibandingkan dengan pengaruh di KBI.
\end{abstract}

\section{Kata Kunci: Pengeluaran Pemerintah, Investasi, Kesempatan Kerja, KTI dan KBI.}

\section{PENDAHULUAN}

Kesempatan Kerja di Indonesia merupakan hal krusial, yang tidak pernah selaras dengan jumlah pencari kerja. Akibatnya jumlah pengangguran meningkat, bahkan sekitar setengah juta tenaga kerja Indonesia mengalir ke luar negeri untuk mencari kerja dan penghidupan layak setiap tahun. Kondisi ini sangat tidak sesuai dengan Pasal 27 ayat 2 UUD 1945 yang berbunyi "Tiap- tiap warga Negara berhak atas pekerjaan dan penghidupan yang layak". Kata kunci untuk mengatasi pengangguran adalah pembukaan kesempatan kerja seluas luasnya, sementara pengeluaran pemerintah dan investasi merupakan jawaban untuk pembukaan kesempatan kerjaitu.

Indonesia merupakan satu satunya Negara di dunia yang memiliki wilayah pulau terbanyak dan wilayah laut terluas, kaya sumber daya alam dan sumber daya manusia, aneka ragam suku, budaya, agama dan aspek sosial lainnya. Namun sejak merdeka pada tahun 1945 belum ada satu pemerintahan dari 7 Presiden yang mampu mengatasi masalah pengangguran dan kemiskinan serta disparitas pembangunan ekonomi antar wilayah dan ukuran ekonomi makro lainnya secara signifikan, bahkan setelah dibentuknya kementerian yang secara khusus menangani percepatan pembangunan daerah tertinggal. Kondisi ini diperparah lagi oleh Negara tetangga dan berbagai 
Negara lain yang menjanjikan pekerjaan dan penghidupan layak yang jauh diatas standar hidup di kampung halaman sendiri (Portal Nasional RI, 2012). Berdasarkan BNP2TKI (2013) data 10 negara sebagai program kerjasama $G$ to $G$ (Government to Government), tingkat kesejahteraan hidup di Indonesia berada pada posisi terendah, sekitar 2 kali di bawah Malaysia atau 14 kali di bawah Australia, bahkan masih lebih rendah dari Papua Nugini, Negara tetangga di sebelah Timur.

Faktor ekonomi yang dibutuhkan untuk mengatasi masalah tersebut adalah besarnya porsi pengeluaran pemerintah, sebaran investasi dan pemerataan kesempatan kerja. Pada Tabel 1. disajikan data besarnya Pengeluaran Pemerintah, Investasi dan Kesempatan Kerja di Indonesia dalam kurun waktu mulai tahun 2001 hingga tahun 2014 (BPS Indonesia, 2014). Kondisi ini diperparah lagi oleh Negara tetangga dan berbagai Negara lain yang menjanjikan pekerjaan dan penghidupan layak yang jauh diatas standar hidup di kampung halaman sendiri (Portal Nasional RI, 2012). Berdasarkan BNP2TKI (2013) data 10 negara sebagai program kerjasama $\mathrm{G}$ to $\mathrm{G}$ (Government to Government), tingkat kesejahteraan hidup di Indonesia berada pada posisi terendah, sekitar 2 kali di bawah Malaysia atau 14 kali di bawah Australia, bahkan masih lebih rendah dari Papua Nugini, Negara tetangga di sebelah Timur.

Faktor ekonomi yang dibutuhkan untuk mengatasi masalah tersebut adalah besarnya porsi pengeluaran pemerintah, sebaran investasi dan pemerataan kesempatan kerja. Pada Tabel 1. disajikan data besarnya Pengeluaran Pemerintah, Investasi dan Kesempatan Kerja di Indonesia dalam kurun waktu mulai tahun 2001 hingga tahun 2014 (BPS Indonesia, 2014).

Tabel 1

Pengeluaran Pemerintah, Investasi, Kesempatan Kerja dan Pertumbuhannya di Indonesia dari tahun 2001-2014

\begin{tabular}{|c|c|c|c|c|c|c|}
\hline Tahun & $\begin{array}{c}\text { Pengel. } \\
\text { Pemerintah } \\
\text { (Miliar Rp.) }\end{array}$ & $\begin{array}{c}\text { Kenaikan } \\
\mathbf{( \% )}\end{array}$ & $\begin{array}{c}\text { Investasi } \\
\text { (Miliar } \\
\text { Rp.) }\end{array}$ & $\begin{array}{c}\text { Kenaikan } \\
\mathbf{( \% )}\end{array}$ & $\begin{array}{c}\text { Kesempatan } \\
\text { Kerja } \\
\text { (Orang) }\end{array}$ & $\begin{array}{c}\text { Kenaikan } \\
(\%)\end{array}$ \\
\hline 2001 & 97.646 & - & 293.793 & - & 83.729 .256 & - \\
\hline 2002 & 110.334 & 12,9 & 307.585 & 4,7 & 85.320 .112 & 1,9 \\
\hline 2003 & 121.404 & 10,1 & 309.431 & 0,6 & 87.367 .795 & 2,4 \\
\hline 2004 & 126.249 & 3,9 & 354.561 & 14,6 & 89.289 .886 & 2,2 \\
\hline 2005 & 134.626 & 6,6 & 393.501 & 10,9 & 92.415 .032 & 3,5 \\
\hline 2006 & 147.564 & 9,6 & 403.719 & 2,6 & 95.177 .102 & 3,0 \\
\hline 2007 & 153.310 & 3,9 & 441.362 & 9,3 & 97.583 .141 & 2,5 \\
\hline 2008 & 169.297 & 10,4 & 493.822 & 11,9 & 102.049 .857 & 4,6 \\
\hline 2009 & 195.834 & 15,7 & 510.100 & 3,3 & 104.485 .444 & 2,4 \\
\hline 2010 & 196.399 & 0,3 & 553.443 & 8,5 & 107.405 .572 & 2,8 \\
\hline 2011 & 219.574 & 11,8 & 567.279 & 2,5 & 111.281 .744 & 3,6 \\
\hline 2012 & 240.873 & 9,7 & 622.305 & 9,7 & 112.802 .805 & 1,4 \\
\hline 2013 & 258.938 & 7,5 & 655.910 & 5,4 & 114.021 .189 & 1,1 \\
\hline 2014 & 264.894 & 2,3 & 687.393 & 4,8 & 115.959 .549 & 1,7 \\
\hline
\end{tabular}

Sumber: Booklet BPS Indonesia 2014. 
Berdasarkan data dalam Tabel 1 dapat dijelaskan bahwa hubungan antara Pengeluaran Pemerintah, Investasi dan Kesempatan Kerja tampak tidak bertumbuh searah, misalnya dari tahun 2006 ke tahun 2007 Pertumbuhan Pengeluaran Pemerintah turun dari 9,6 persen ke 3,9 persen. Penurunan ini menyebabkan Investasi malah bertumbuh dari 2,6 persen ke 9,3 persen. Sementara Kesempatan Kerja menurun dari 3,0 persen ke 2,5 persen. Berbeda kondisi dari tahun 2007 ke tahun 2008 yang Pertumbuhan Pengeluaran Pemerintah naik dari 3,9 persen ke 10,4 persen, sementara Investasi dan Kesempatan Kerja justeru juga naik masing masing dari 9,3 persen ke 11,9 persen dan dari 2,5 persen ke 4,6 persen. Selanjutnya, dari tahun 2008 ke tahun 2009
Pertumbuhan Pengeluaran Pemerintah berlanjut naik dari 10,4 persen ke 15,7 persen, tetapi Investasi dan Kesempatan Kerja justeru mengalami penurunan dari 11,9 persen ke 3,3 persen dan dari 4,6 persen ke 2,4 persen. Lebih lanjut, dari tahun 2009 ke tahun 2010 Pertumbuhan Pengeluaran Pemerintah terhempas tajam dari 15,7 persen ke hanya 0,3 persen saja, Pertumbuhan Investasi justeru naik tajam dari 3,3 persen ke 8,5 persen, sementara Kesempatan Kerja hanya mengalami pertumbuhan sangat kecil yakni dari 2,4 persen ke 2,8 persen. Kondisi tidak searah ini dalam kurun waktu dari tahun 2001 hingga tahun 2014.

Tabel 1 di atas dapat digambarkan dalam bentuk grafik seperti di bawah ini.

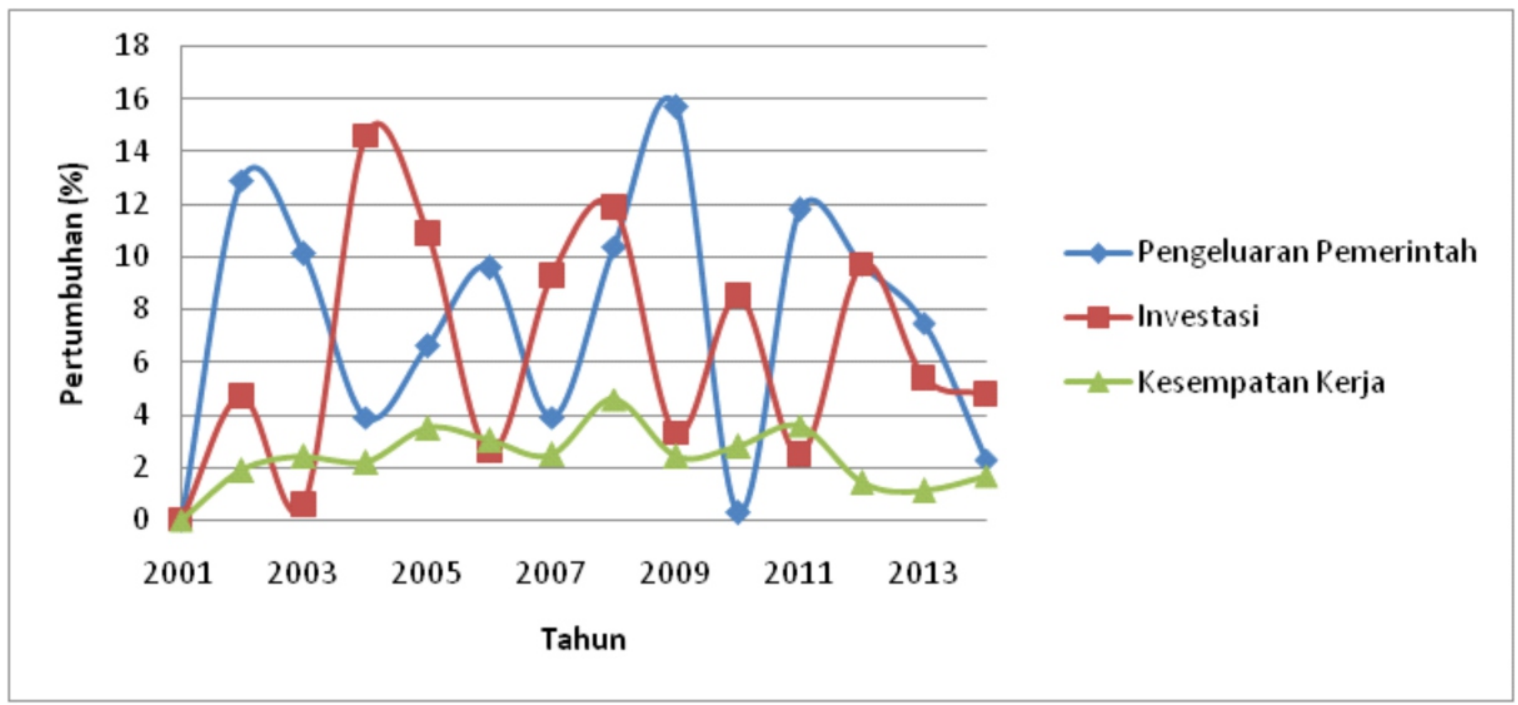

Gambar 1. Grafik Pertumbuhan Pengeluaran Pemerintah, Investasi dan Kesempatan Kerja di Indonesia.

Pada Gambar 1 Pertumbuhan Pengeluaran Pemerintah, Investasi dan Kesempatan Kerja hubungan kausalitasnya tidak searah dari waktu ke waktu. Berkaitan dengan hal tersebut penelitian ini bertujuan untuk menganalisis dan mengukur besarnya: (1) Pengaruh Pengeluaran Pemerintah terhadap Investasi di Kawasan Timur Indonesia (KTI) dan Kawasan Barat Indonesia (KBI); (2) Pengaruh
Pengeluaran Pemeritah terhadap Kesempatan Kerja baik secara langsung maupun secara tidak langsung melalui Investasi di Kawasan Timur Indonesia (KTI) dan di Kawasan Barat Indonesia (KBI); (3) Pengaruh Investasi terhadap Kesempatan Kerja di Kawasan Timur Indonesia (KTI) dan di Kawasan Barat Indonesia (KBI); (4) Perbedaan pengaruh antar kedua wilayah pada 1,2 , dan 3 . 


\section{KAJIAN PUSTAKA}

\subsection{Pengaruh Investasi terhadap Kesempatan Kerja}

Faktor utama yang menentukan sebuah perekonomian mampu menyediakan kesempatan kerja bagi angkatan kerja adalah akumulasi modal yang akan melakhirkan berbagai proyek investasi yang selanjutnya akan menyediakan kesempatan kerja. Akan tetapi akumulasi modal hanyalah syarat perlu bagi terciptanya proyek proyek. Syarat cukupnya masih banyak, diantaranya situasi perekonomian yang kondusif supaya investor bergairah $\mathrm{m} \mathrm{e} 1$ a k u k a i n v e t a s i (Wahyuningtyas,2010). Jika situasi perekonomian tidak kondusif misalnya sedang mengalami resesi, maka barang barang yang diproduksi tidak akan menemukan permintaan yang signifikan sehingga para investor enggan melakukan investasi meskipun kapitalnya tersedia. Sebagai akibatnya tidak akan banyak proses produksi yang akan menciptakan kesempatan kerja untuk menyerap angkatan kerja (Hakim Abdul, 2002). Besar kecilnya minat atau kegairahan Investasi baik Penanaman Modal Asing(PMA) maupun Penanaman Modal Dalam Negeri (PMDN) pada suatu Negara sangat tergantung pada berbagai faktor. Adapun faktor faktor yang mempengaruhi investasi di Indonsia (Nugroho, 2008) adalah: SDA, SDM, Stabilitas Politik dan Perekonomian, Stabilitas Kebijakan Pemerintah, Kemudahan dalam Perizinan, Inflasi, Etika Kerja dan Tenaga Kerja, Tingkat Kriminalitas, Regulasi valas, Akses ke Keuangan, Tarif Pajak, Regulasi Tenaga Kerja, Regulasi Perpajakan, Kondisi Infra Struktur, Tingkat keefisienan Birokrasi, suku bunga, faktor sosial budaya, dan lain lainnya.

Investasi dapat mempunyai multiplier effect yang besar (Risvi, 2009) karena investasi akan mendorong peningkatan baik di sisi produksi maupun sisi konsumsi. Dengan peningkatan di kedua sisi tersebut akan menyebabkan terbentuknya pertumbuhan ekonomi. Multiplier effect dari investasi dapat dilihat dari sisi produksi yaitu produksi akan tergenjot karena investasi akan memberikan ketersediaan sarana dan prasarana untuk melaksanakan produksi menjadi lebih baik. Selanjutnya, untuk berproduksi dibutuhkan sumber daya manusia yang lebih banyak sehingga akan mendorong pembukaan dan perluasan lapangan pekerjaan (Hendarmin, 2012). Berbagai pandangan ini sesuai dengan teori Lewis, teori Ranis-Fei dan teori Harrod Domar, bahkan teori Investasi itu sendiri yang berpengaruh langsung pada tiga hal; perluasan kesempatan kerja, pertumbuhan ekonomi dan pengentasan kemiskinan.

\subsection{Pengaruh Pengeluaran Pemerintah terhadap Kesempatan Kerja.}

Pengeluaran pemerintah (goverment expenditure) adalah bagian dari kebijakan fiskal (Hakim Abdul ,2002) yakni suatu tindakan pemerintah untuk mengatur jalannya perekonomian dengan cara menentukan besarnya penerimaan dan pengeluaran pemerintah tiap tahunnya yang tercermin dalam dokumen APBN untuk nasional dan APBD untuk daerah/regional. Tujuan dari kebijakan fiskal ini adalah dalam rangka menstabilkan harga, tingkat output maupun kesempatan kerja dan memacu pertumbuhan ekonomi. Pengeluaran Pemerintah dapat ikut mendorong pertumbuhan ekonomi melalui penyerapan tenaga kerja. Menurut Barro (2001) dan Sun'an (2008), kontribusi pengeluaran produktif akan berpengaruh positif terhadap Kesempatan Kerja, sebaliknya untuk pengeluaran yang tidak produktif akan berpengaruh negatif terhadap Kesempatan Kerja. 
Sebagian dari Pengeluaran Pemerintah itu langsung diperuntukkan untuk pembukaan kesempatan kerja baru misalnya penerimaan Pegawai Negeri Sipil, Polisi dan Militer (Raharja,2008). Penelitian yang dilakukan oleh Noah Karley (2000) di Benua Afrika pada tahun 2000 ditemukan pengaruh Pengeluaran Pemerintah terhadap Kesempatan Kerja adalah positif dan signifikan. Penelitian lainnya yang senada dengan Noa adalah penelitian yang dilakukan oleh Cavallo (2005), Berument (2008), Hendarmin (2012).

Tetapi Mankiw,2003 (dalam Suindyah, 2009) menjelaskan bahwa dengan adanya kenaikan pengeluaran pemerintah (ekspansi fiskal) maka akan menghambat investasi, yang pada gilirannya menurunkan kesempatan kerja dan pertumbuhan ekonomi. Landau (dalam Suindyah, 2009) membuktikan bahwa pengeluaran pemerintah di bidang militer dan pendidikan berkorelasi negatif terhadap pertumbuhan ekonomi, sementara untuk pendidikan sendiri berkorelasi kuat dan investasi pemerintah berkorelasi positif tetapi tidak signifikan. Sementara Lin (dalam Maipita, 2012) mengatakan bahwa pengeluaran pemerintah akan meningkatkan pertumbuhan ekonomi (PDB) dengan laju yang semakin mengecil. Lin juga menyatakan bahwa Hukum Wagner hanya berlaku untuk negara maju.

\subsection{Pengaruh Pengeluaran Pemerintah terhadap Investasi}

Pengeluaran Pemerintah dapat menarik masuk (Crawding In) atau mendesak keluar (Crawding Out) suatu Investasi, tergantung pada faktor faktor yang mempegaruhinya (Risvi, 2009). Ada beberapa faktor yang mempengaruhi investasi (Liste, 2012) yaitu; Suku bunga, pendapatan nasional, kondisi sarana prasarana (infrastructure), birokrasi perizinan, kualitas sumber daya manusia, peraturan dan undang-undang ketenagakerjaan. stabilitas politik dan keamanan, sosial budaya.

Hal ini berarti Pengaruh Pengeluaran Pemerintah terhadap Investasi adalah dapat positif(Crawding In) dan dapat pula negatif (Crawding Out). Untuk pengaruh positif akibat dari peningkatan pengeluaran pemerintah maka menyebabkan akan diikuti dengan peningkatan investasi (PMDN dan PMA) dengan asumsi faktor faktor lain yang mempengaruhi variabilitas pengeluaran pemerintah adalah konstan (Liste,2012). Salah satu tujuan dari peningkatan pengeluaran pemerintah (Hukum Wagner) adalah perbaikan berbagai infrastruktur Negara seperti jalan raya, sarana prasarana pendidikan dan kesehatan sehingga para Investor tertarik untuk menanamkan modalnya atau semakin meningkatkan penanaman modalnya (Crawding In). Sebaliknya, naiknya pengeluaran pemerintah disaat kurva LM sangat tidak elastis membuat para Investor mengurangi investasinya(Crawding Out).

Kasus di Indonesia adalah Crawding In, bukan Crawding Out, karena itu dapat ditafsirkan bahwa pengalokasian dana APBN dan APBD yang didalamnya termuat antara lain pengeluaran pemerintah berdampak positif terhadap peningkatan investasi. Beberapa penelitian empiris yang mendukung/sesuai dan bertentangan dengan penelitian ini adalah penelitian yang dilakukan oleh Prasetia (2011) dan Sasana (2009), keduanya juga berpengaruh Crawding In. Sementara penelitian yang dilakukan oleh Ramey (2012) berpengaruh Crawding Out dan Ahmadi (2012) tidak signifikan dan tidak berpengaruh. Sejumlah penelitian yang antara lain meneliti pengaruh Pengeluaran Pemerintah terhadap Investasi adalah Wahyuningtyas, Agustina Endah (2010), Petrus, Irene Lilian (2010), SEKI (2011) yang menemukan pengaruh positif (Crawding In) dan sejumlah penelitian yang menemukan pengaruh 
negatif (Crawding Out) seperti penelitian yang dilakukan oleh Valerie A. Ramey dan NBER (2012).

\section{KERANGKA KONSEPTUAL \& HIPOTESIS}

\subsection{Kerangka Konseptual}

Kerangka Konseptual diawali dengan menyatakan model fungsional yang dipilih, dilanjutkan dengan menentukan bentuk fungsi nonlinier dan kemudian mengkonversi menjadi bentuk fungsi linier yang digunakan untuk menggambarkan kerangka konseptual. Adapun tahapan ini dirangkum dalam Tabel2.

Tabel 2

Bentuk Fungsional, Model Nonlinier dan transformasi Model Linier

\begin{tabular}{|c|c|c|}
\hline Model Fungsional & Bentuk Fungsi Nonlinier & Bentuk Fungsi Linier \\
\hline $\mathrm{Y}_{1}=\mathrm{f}\left(\mathrm{X}_{1}, \mathrm{X}_{2}, \mathrm{X}_{3}\right)$ & $\mathrm{Y}_{1}=\alpha_{0} \mathrm{X}_{1}{ }^{\alpha_{1}} \mathrm{e}^{\left(a_{2} \mathrm{X}_{2}+\alpha_{3} \mathrm{X}_{3}+\varepsilon_{1}\right)}$ & $\begin{array}{c}\ln Y_{1}=\ln \alpha_{0}+\alpha_{1} \ln X_{1}+\alpha_{2} \mathrm{X}_{2}+\alpha_{3} \mathrm{X}_{3}+\varepsilon_{1} \\
\mathrm{Y}_{1}^{*}=\alpha_{0}^{*}+\alpha_{1} \mathrm{X}_{1}^{*}+\alpha_{2} \mathrm{X}_{2}+\alpha_{3} \mathrm{X}_{3}+\varepsilon_{1}\end{array}$ \\
\hline $\mathrm{Y}_{2}=\mathrm{f}\left(\mathrm{X}_{1}, \mathrm{X}_{2}, \mathrm{X}_{3}, \mathrm{X}_{4}, \mathrm{Y}_{1}\right)$ & $\mathrm{Y}_{2}=\beta_{0} \mathrm{X}_{1} \beta_{1} \mathrm{Y}_{1}^{\beta_{5}} \mathrm{e}^{\left(\beta_{2} \mathrm{X}_{2}+\beta_{3} \mathrm{X}_{3}+\beta_{4} \mathrm{X}_{4}+\varepsilon_{2}\right)}$ & $\begin{array}{c}\ln Y_{2}=\ln \beta_{0}+\beta_{1} \ln X_{1}+\beta_{5} \ln Y_{1}+\beta_{2} \mathrm{X}_{2}+\beta_{3} \mathrm{X}_{3}+\beta_{4} \mathrm{X}_{4}+\varepsilon_{2} \\
\mathrm{Y}_{2}^{*}=\beta_{0}^{*}+\beta_{1} \mathrm{X}_{1}^{*}+\beta_{5} \mathrm{Y}_{1}^{*}+\beta_{2} \mathrm{X}_{2}+\beta_{3} \mathrm{X}_{3}+\beta_{4} \mathrm{X}_{4}+\varepsilon_{2}\end{array}$ \\
\hline $\mathrm{X}_{3}=\mathrm{f}\left(\mathrm{X}_{1}, \mathrm{X}_{2}\right)$ & $e^{X_{3}}=X_{1}^{X_{2}}$ & $X_{3}=X_{2} \ln X_{1}=\mathrm{X}_{2} \mathrm{X}_{1}^{*}$ \\
\hline$X_{4}=f\left(X_{2}, Y_{1}\right)$ & $e^{X_{4}}=Y_{1}^{X_{2}}$ & $X_{4}=X_{2} \ln Y_{1}=\mathrm{X}_{2} \mathrm{Y}_{1}^{*}$ \\
\hline
\end{tabular}

Sumber: Dijabarkan sendiri.

Berdasarkan Model Linier pada Tabel 2 dapat digambarkan kerangka konseptual seperti Gambar 2.

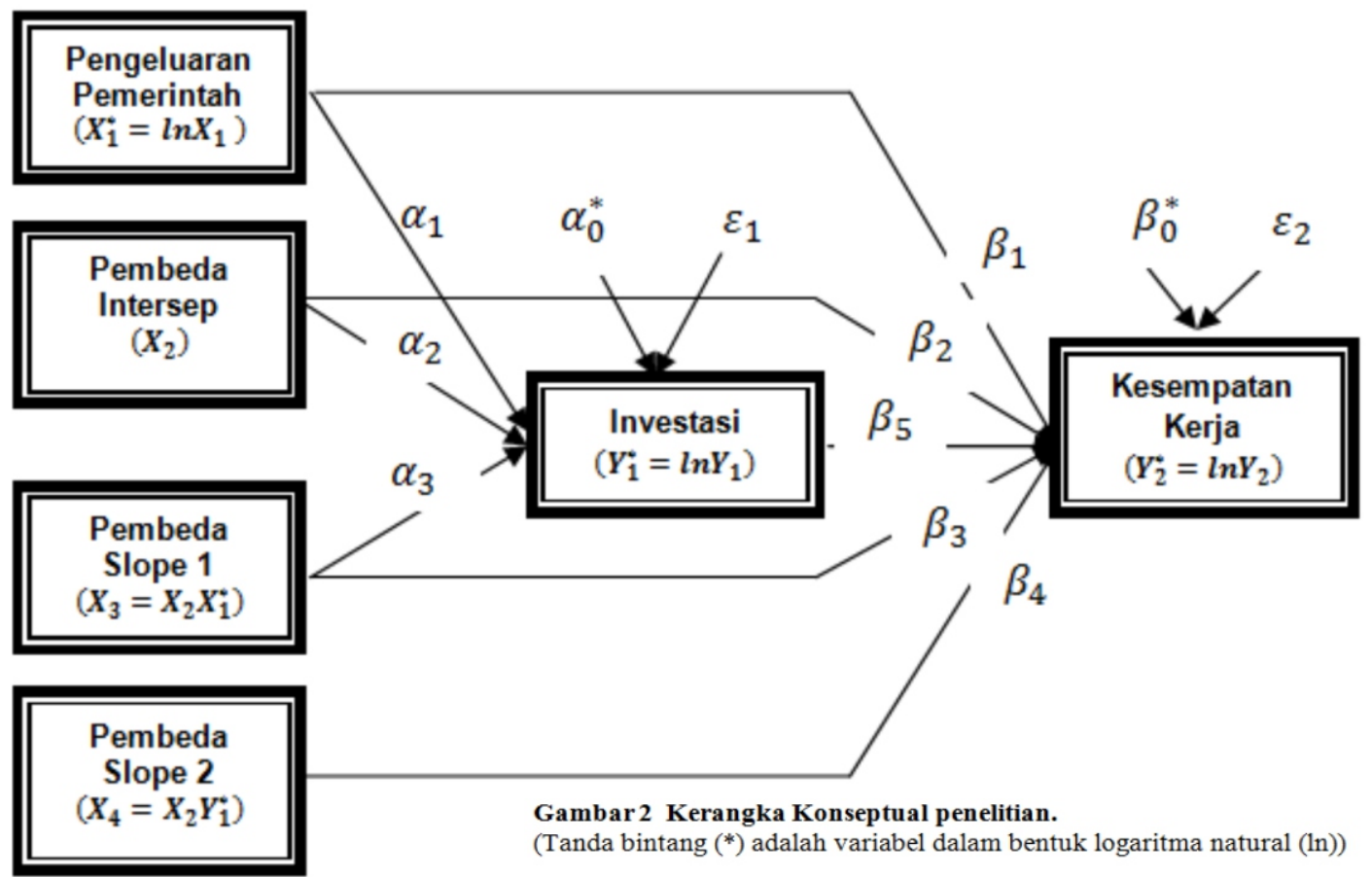

Keterangan Gambar 2

$\mathrm{X}_{1}$ : Pengeluaran Pemerintah (Government Expenditure)

$\mathrm{X}_{2}$ : Variabel Dummy (Pembeda Intersep) KTI dengan KBI pada Investasi dan pada Kesempatan Kerja.

$\mathrm{X}_{3}$ : Variabel Kontrol (Pembeda Slope 1) KTI dengan KBI dari Pengeluaran Pemerintah terhadap Kesempatan Kerja.

$\mathrm{X}_{4}$ : Variabel Kontrol (Pembeda Slope 2) KTI dengan KBI dari Investasi terhadap Kesempatan Kerja.

$$
\begin{aligned}
& \mathrm{Y}_{1}: \text { Investasi } \\
& \mathrm{Y}_{2}: \text { Kesempatan Kerja } \\
& \alpha_{0}^{*}=\ln \alpha_{0}=\text { Konstanta Intersep pada } Y_{1}^{*} \\
& \beta_{0}^{*}=\ln \beta_{0}=\text { Konstanta Intersep pada } Y_{2}^{*} \\
& \varepsilon_{1}=\operatorname{Residual} Y_{1}^{*} \\
& \varepsilon_{2}=\text { Residual } Y_{2}^{*}
\end{aligned}
$$


Pada gambar 3.1 semua garis hubungan kausalitas yang menuju ke Investasi menggunakan simbol $\alpha$. Karena ada sebanyak 3 hubungan, maka koefisien $\alpha$ ada sebanyak 3 buah yaitu $\alpha_{1}, \alpha_{2}$ dan $\alpha_{3}$. Sementara yang menuju ke Kesempatan Kerja menggunakan simbol $\beta$ dan ada sebanyak 5 hubungan yakni kofisien $\beta_{1}$ sampai $\beta_{5}$. Koefisien koefisien ini merupakan koefisien Slope, ditambah dengan konstanta Intersep $\alpha_{0}^{*}$ dan $\beta_{0}^{*}$ serta factor residual (error) $\varepsilon_{1}$ dan $\varepsilon_{2}$.

\subsection{Hipotesis Penelitian}

1.Pengeluaran Pemerintah berpengaruh positif dan signifikan terhadap Investasi di KTI dan di KBI.

2.Pengeluaran Pemerintah berpengaruh positif dan signifikan terhadap Kesempatan Kerja di KTI dan di KBI, baik secara langsung dan secara tidak langsung melalui Investasi maupun secara total.

3.Investasi berpengaruh positif dan signifikan terhadap Kesempatan Kerja di KTI dan di KBI.

4.Ada perbedaan pengaruh dan sgnifikan pada masing masing hipotesis 1,2 , dan 3 antara KBI dengan KTI.

\section{METODE PENELITIAN}

\subsection{Lokasi, Sumber dan Periode Data Penelitian}

Penelitian ini meliputi 34 provinsi di Indonesia, 17 provinsi di Bagian Timur yakni 5 di Kalimantan, 6 di Sulawesi, 2 di Nusa Tenggara, 2 di Maluku, dan 2 di Papua. Sementara di Kawasan Barat Indonesia juga 17 provinsi yakni 1 di Bali, 6 di Jawa, 10 di Sumatera. Pembagian menjadi 2 Wilayah ini dimaksudkan untuk melihat Pengaruh Pengeluaran Pemerintah terhadap kedua wilayah ini yang diduga memiliki perbedaan yang berdampak pada mengalirnya tenaga kerja dari Kawasan Timur Indonesia (KTI) ke Kawasan Barat Indonesia $(\mathrm{KBI})$ dan mengalirnya tenaga kerja Indonesia sebagai TKI ke luar negeri. Periode Tahun Penelitian adalah 7 tahun yaitu dari tahun 2007 hingga tahun 2013. Hal ini didasarkan pada pertimbangan bahwa untuk mengeksekusi program statistic diperlukan paling sedikit 100 data untuk setiap variabel, sehingga dengan peroide 7 tahun (data time series) dikali 33 Provinsi (data cross section) diperoleh jumlah data pooled (panel data) per variabel sebanyak 231 data, jauh diatas data minimal yang diperlukan. Jenis data adalah data sekunder yang bersumber dari Badan Pusat Statistik (BPS) dan Sumber lainnya seperti Jurnal, Bulletin dan Artikel.

\subsection{Metode Pengumpulan Data dan Variabel Penelitian}

Penelitian ini menggunakan metode pengumpulan data setting alamiah, sumber data sekunder dan cara dokumentasi dengan tiga buah variabel Penelitian yakni Pengeluaran Pemerintah, Investasi dan Kesempatan Kerja ditambah sebuah variabel Dummy sebagai pembeda intersep serta dua buah variabel Kontrol sebagai pembeda Slope antara wilayah KTI dengan wilayah KBI.

\subsection{Teknik Analsis Data}

Penelitian ini menggunakan Struktural Equation Modelling (SEM) dengan persamaan struktural model fungsional, bentuk fungsi linier hasil konversi seperti yang dinyatakan dalam Tabel 2 dan Gambar 2. Menggunakan panel data sekunder dari 34 provinsi di Indonesia selama 7 tahun dari tahun 2007 sampai tahun 2013 (BPS,2014). Selanjutnya untuk melakukan analisis data, persamaan bentuk linier dalam Tabel 2, $\mathrm{X}_{3}$ dan $\mathrm{X}$ 4harus disubstitusi ke dalamY dan Y diperoleh persamaan persamaan seperti dalam Tabel 3. 
Tabel 3 Persamaan persamaan secara umum, KTI, dan KBI

\begin{tabular}{|c|c|c|}
\hline Untuk & Persamaan & Keterangan \\
\hline \multirow{3}{*}{$\begin{array}{l}\text { Secara Umum } \\
\quad\left(\operatorname{dlm} X_{2}\right)\end{array}$} & $\mathbf{Y}_{1}^{*}=\left(\alpha_{0}^{*}+\alpha_{2} \mathbf{X}_{2}\right)+\left(\alpha_{1}+\alpha_{3} \mathbf{X}_{2}\right) \mathbf{X}_{1}^{*}+\varepsilon_{1}$ & \\
\hline & $\mathbf{Y}_{2}^{*}=\left(\boldsymbol{\beta}_{0}^{*}+\boldsymbol{\beta}_{2} \mathbf{X}_{2}\right)+\left(\boldsymbol{\beta}_{1}+\boldsymbol{\beta}_{3} \mathbf{X}_{2}\right) \mathbf{X}_{1}^{*}+\left(\boldsymbol{\beta}_{5}+\boldsymbol{\beta}_{4} \mathbf{X}_{2}\right) \mathbf{Y}_{1}^{*}+\varepsilon_{2}$ & \\
\hline & $\begin{aligned} \mathbf{Y}_{2}^{*}= & {\left[\left(\boldsymbol{\beta}_{0}^{*}+\boldsymbol{\beta}_{2} \mathbf{X}_{2}\right)+\left(\boldsymbol{\beta}_{5}+\boldsymbol{\beta}_{4} \mathbf{X}_{2}\right)\left(\boldsymbol{\alpha}_{0}^{*}+\boldsymbol{\alpha}_{2} \mathbf{X}_{2}\right)\right] } \\
& +\left[\left(\boldsymbol{\beta}_{1}+\boldsymbol{\beta}_{3} \mathbf{X}_{2}\right)+\left(\boldsymbol{\beta}_{5}+\boldsymbol{\beta}_{4} \mathbf{X}_{2}\right)\left(\boldsymbol{\alpha}_{1}+\boldsymbol{\alpha}_{3} \mathbf{X}_{2}\right)\right] \mathbf{X}_{1}^{*} \\
& +\left[\left(\boldsymbol{\beta}_{5}+\boldsymbol{\beta}_{4} \mathbf{X}_{2}\right) \varepsilon_{1}+\boldsymbol{\varepsilon}_{2}\right]\end{aligned}$ & Reduce Form \\
\hline \multirow{3}{*}{$\begin{array}{c}\text { KTI } \\
\left(X_{2}=1\right)\end{array}$} & $\mathbf{Y}_{1}^{*}=\left(\alpha_{0}^{*}+\alpha_{2}\right)+\left(\alpha_{1}+\alpha_{3}\right) \mathbf{X}_{1}^{*}+\varepsilon_{1}$ & \\
\hline & $\mathbf{Y}_{2}^{*}=\left(\boldsymbol{\beta}_{0}^{*}+\boldsymbol{\beta}_{2}\right)+\left(\boldsymbol{\beta}_{1}+\boldsymbol{\beta}_{3}\right) \mathbf{X}_{1}^{*}+\left(\boldsymbol{\beta}_{5}+\boldsymbol{\beta}_{4}\right) \mathbf{Y}_{1}^{*}+\varepsilon_{2}$ & \\
\hline & $\begin{array}{c}\mathbf{Y}_{2}^{*}=\left[\left(\boldsymbol{\beta}_{0}^{*}+\boldsymbol{\beta}_{2}\right)+\left(\boldsymbol{\beta}_{5}+\boldsymbol{\beta}_{4}\right)\left(\boldsymbol{\alpha}_{0}^{*}+\boldsymbol{\alpha}_{2}\right)\right]+\left[\left(\boldsymbol{\beta}_{1}+\boldsymbol{\beta}_{3}\right)+\left(\boldsymbol{\beta}_{5}+\boldsymbol{\beta}_{4}\right)\left(\boldsymbol{\alpha}_{1}+\boldsymbol{\alpha}_{3}\right)\right] \mathbf{X}_{1}^{*} \\
+\left[\left(\boldsymbol{\beta}_{5}+\boldsymbol{\beta}_{4}\right) \varepsilon_{1}+\varepsilon_{2}\right]\end{array}$ & Reduce Form \\
\hline \multirow{3}{*}{$\begin{array}{c}\text { KBI } \\
\left(X_{2}=0\right)\end{array}$} & $\mathbf{Y}_{1}^{*}=\left(\alpha_{0}^{*}\right)+\left(\alpha_{1}\right) \mathbf{X}_{1}^{*}+\varepsilon_{1}$ & \\
\hline & $\mathbf{Y}_{2}^{*}=\left(\boldsymbol{\beta}_{0}^{*}\right)+\left(\boldsymbol{\beta}_{1}\right) \mathbf{X}_{1}^{*}+\left(\boldsymbol{\beta}_{5}\right) \mathbf{Y}_{1}^{*}+\varepsilon_{2}$ & \\
\hline & $\mathbf{Y}_{2}^{*}=\left[\left(\boldsymbol{\beta}_{0}^{*}\right)+\left(\beta_{5}\right)\left(\alpha_{0}^{*}\right)\right]+\left[\left(\beta_{1}\right)+\left(\beta_{5}\right)\left(\alpha_{1}\right)\right] \mathbf{X}_{1}^{*}+\left[\left(\beta_{5}\right) \varepsilon_{1}+\varepsilon_{2}\right]$ & Reduce Form \\
\hline
\end{tabular}

Sumber: Diturunkan dari Tabel 2

Berdasarkan Tabel 3 diperoleh konstanta Intersep, koefisien Slope dan nilai residual seperti yang dinyatakan dalam Tabel 4 .

Tabel 4 Intersep, Slope dan Residual (Error) secara umum, KTI, dan KBI

\begin{tabular}{|c|c|c|c|c|}
\hline Untuk & Hubungan & Intersep & Slope & Residual \\
\hline \multirow{3}{*}{$\begin{array}{c}\text { Secara } \\
\text { Umum } \\
\left(\operatorname{dlm} X_{2}\right)\end{array}$} & $Y_{1}^{*} \leftarrow X_{1}^{*}$ & $\left(\alpha_{0}^{*}+\alpha_{2} X_{2}\right)$ & $\left(\alpha_{1}+\alpha_{3} X_{2}\right)$ & $\varepsilon_{1}$ \\
\hline & $Y_{2}^{*} \leftarrow Y_{1}^{*} \leftarrow X_{1}^{\prime}$ & $\left(\beta_{0}^{*}+\beta_{2} X_{2}\right)$ & $\left(\beta_{1}+\beta_{3} X_{2}\right) \&\left(\beta_{5}+\beta_{4} X_{2}\right)$ & $\varepsilon_{2}$ \\
\hline & $Y_{2 T}^{\prime} \leftarrow X_{1 T}^{\prime}$ & {$\left[\left(\beta_{0}^{t}+\beta_{2} X_{2}\right)+\left(\beta_{5}+\beta_{4} X_{2}\right)\left(\alpha_{0}^{j}+\alpha_{2} X_{2}\right)\right]$} & {$\left[\left(\beta_{1}+\beta_{3} X_{2}\right)+\left(\beta_{5}+\beta_{4} X_{2}\right)\left(\alpha_{1}+\alpha_{3} X_{2}\right)\right]$} & {$\left[\left(\beta_{5}+\beta_{4} X_{2}\right) \varepsilon_{1}+\varepsilon_{2}\right]$} \\
\hline \multirow{3}{*}{$\begin{array}{c}\text { KTI } \\
\left(X_{2}=1\right)\end{array}$} & $Y_{1}^{i} \leftarrow X_{1}^{*}$ & $\left(\alpha_{0}^{*}+\alpha_{2}\right)$ & $\left(\alpha_{1}+\alpha_{3}\right)$ & $\varepsilon_{1}$ \\
\hline & $Y_{2}^{*} \leftarrow Y_{1}^{*} \leftarrow X_{1}^{*}$ & $\left(\beta_{0}^{*}+\beta_{2}\right)$ & $\left(\beta_{1}+\beta_{3}\right) \&\left(\beta_{5}+\beta_{4}\right)$ & $\varepsilon_{2}$ \\
\hline & $Y_{2 T}^{\prime} \leftarrow X_{1 T}^{\prime}$ & $\left.\left(\beta_{0}^{\prime}+\beta_{2}\right)+\left(\beta_{5}+\beta_{4}\right)\left(\alpha_{0}^{*}+\alpha_{2}\right)\right]$ & {$\left[\left(\beta_{1}+\beta_{3}\right)+\left(\beta_{5}+\beta_{4}\right)\left(\alpha_{1}+\alpha_{3}\right)\right]$} & {$\left[\left(\beta_{5}+\beta_{4}\right) \varepsilon_{1}+\varepsilon_{2}\right]$} \\
\hline \multirow{3}{*}{$\begin{array}{c}\text { KBI } \\
\left(X_{2}=0\right)\end{array}$} & $Y_{1}^{*} \leftarrow X_{1}^{*}$ & $\left(\alpha_{0}^{*}\right)$ & $\left(\alpha_{1}\right)$ & $\varepsilon_{1}$ \\
\hline & $Y_{2}^{*} \leftarrow Y_{1}^{*} \leftarrow X_{1}^{*}$ & $\left(\beta_{0}^{*}\right)$ & $\left(\beta_{1}\right) \&\left(\beta_{5}\right)$ & $\varepsilon_{2}$ \\
\hline & $Y_{2 T}^{*} \leftarrow X_{1 T}^{*}$ & $\left.\left(\beta_{0}^{*}\right)+\left(\beta_{5}\right)\left(\alpha_{0}^{*}\right)\right]$ & {$\left[\left(\beta_{1}\right)+\left(\beta_{5}\right)\left(\alpha_{1}\right)\right]$} & $\left.\left(\beta_{5}\right) \varepsilon_{1}+\varepsilon_{2}\right]$ \\
\hline
\end{tabular}

Sumber: Tabel 3 ,

Selanjutnya, pengaruh langsung dan tidak langsung serta pengaruh total dapat digambarkan seperti gambar 3 dan Tabel 5.

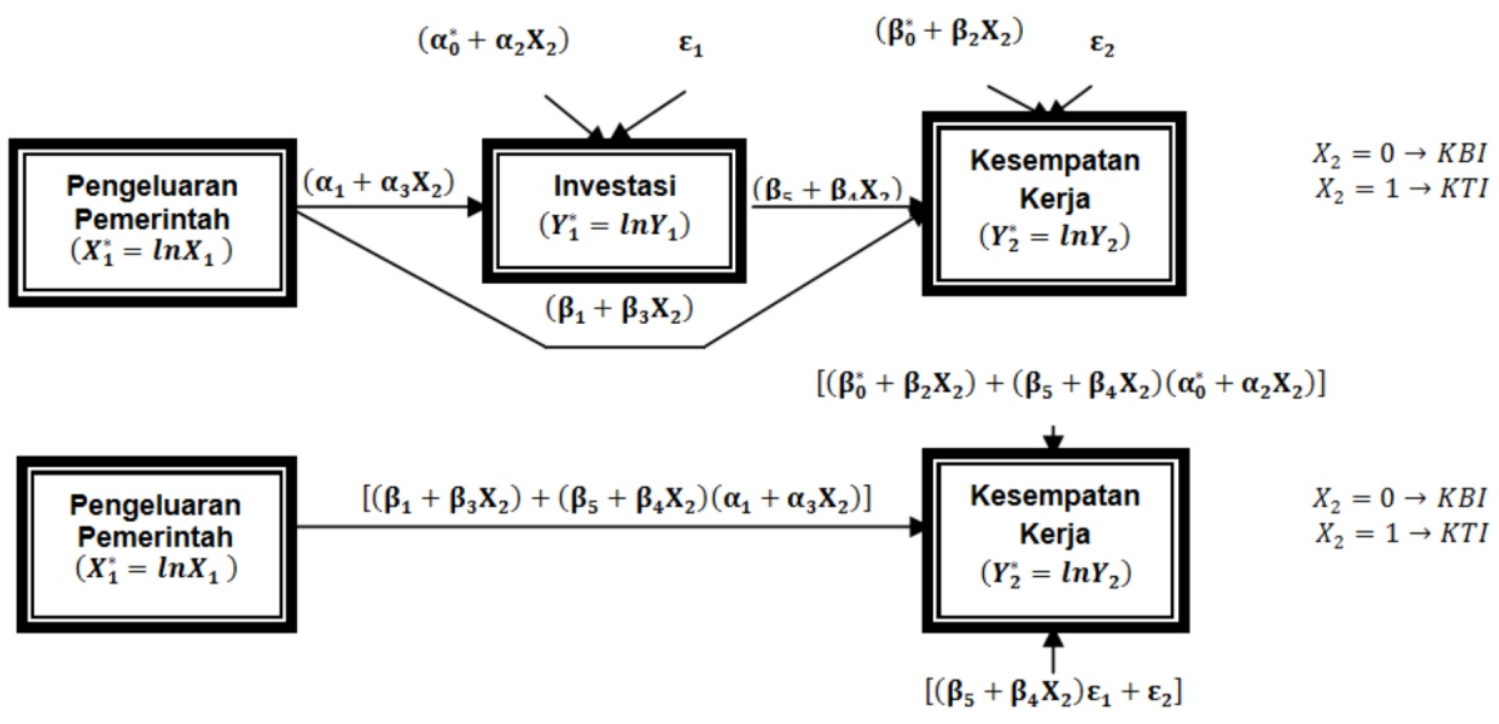


Gambar 3 Pengaruh Langsung, Tidak Langsung dan Total antar Variabel Tabel 5 Tabel hubungan dari Gambar 3

\begin{tabular}{|c|c|c|c|c|c|}
\hline \multicolumn{2}{|c|}{ Pengaruh } & Umum & $\begin{array}{c}\text { KBI } \\
\left(X_{2}=0\right)\end{array}$ & $\begin{array}{c}\text { KTI } \\
\left(X_{2}=1\right)\end{array}$ & $\Delta$ \\
\hline Langsung & $\begin{array}{c}\mathrm{PP} \rightarrow \mathrm{KK} \\
\mathrm{PP} \rightarrow \mathrm{INV} \\
\mathrm{INV} \rightarrow \mathrm{KK} \\
\end{array}$ & $\begin{array}{l}\left(\beta_{1}+\beta_{3} \mathbf{X}_{2}\right) \\
\left(\alpha_{1}+\alpha_{3} \mathbf{X}_{2}\right) \\
\left(\beta_{5}+\beta_{4} \mathbf{X}_{2}\right)\end{array}$ & $\begin{array}{l}\beta_{1} \\
\alpha_{1} \\
\beta_{5} \\
\end{array}$ & $\begin{array}{l}\left(\beta_{1}+\beta_{3}\right) \\
\left(\alpha_{1}+\alpha_{3}\right) \\
\left(\beta_{5}+\beta_{4}\right)\end{array}$ & $\begin{array}{l}\beta_{3} \\
\alpha_{3} \\
\beta_{4} \\
\end{array}$ \\
\hline $\begin{array}{c}\text { Tidak } \\
\text { Langsung }\end{array}$ & $\mathrm{PP} \rightarrow \mathrm{INV} \rightarrow \mathrm{KK}$ & $\left(\alpha_{1}+\alpha_{3} X_{2}\right)\left(\beta_{5}+\beta_{4} X_{2}\right)$ & $\left(\alpha_{1}\right)\left(\beta_{5}\right)$ & $\left(\alpha_{1}+\alpha_{3}\right)\left(\beta_{5}+\beta_{4}\right)$ & $\left(\alpha_{1}+\alpha_{3}\right)\left(\beta_{4}\right)$ \\
\hline Total & $\mathrm{PP} \rightarrow \mathrm{KK}$ & $\begin{array}{l}{\left[\left(\beta_{1}+\beta_{3} X_{2}\right)\right.} \\
\left.+\left(\beta_{5}+\beta_{4} X_{2}\right)\left(\alpha_{1}+\alpha_{3} X_{2}\right)\right]\end{array}$ & {$\left[\left(\beta_{1}\right)+\left(\beta_{5}\right)\left(\alpha_{1}\right)\right]$} & $\begin{array}{l}{\left[\left(\beta_{1}+\beta_{3}\right)\right.} \\
\left.+\left(\beta_{5}+\beta_{4}\right)\left(\alpha_{1}+\alpha_{3}\right)\right]\end{array}$ & $\begin{array}{l}{\left[\left(\beta_{1}+\beta_{5} \alpha_{3}\right)\right.} \\
\left.+\left(\beta_{4}\right)\left(\alpha_{1}+\alpha_{3}\right)\right]\end{array}$ \\
\hline
\end{tabular}

Sumber: Tabulasi dari Gambar 3

\section{HASIL}

Olah data menggunakan AMOS V21 dan hasilnya adalah seperti Gambar 4.

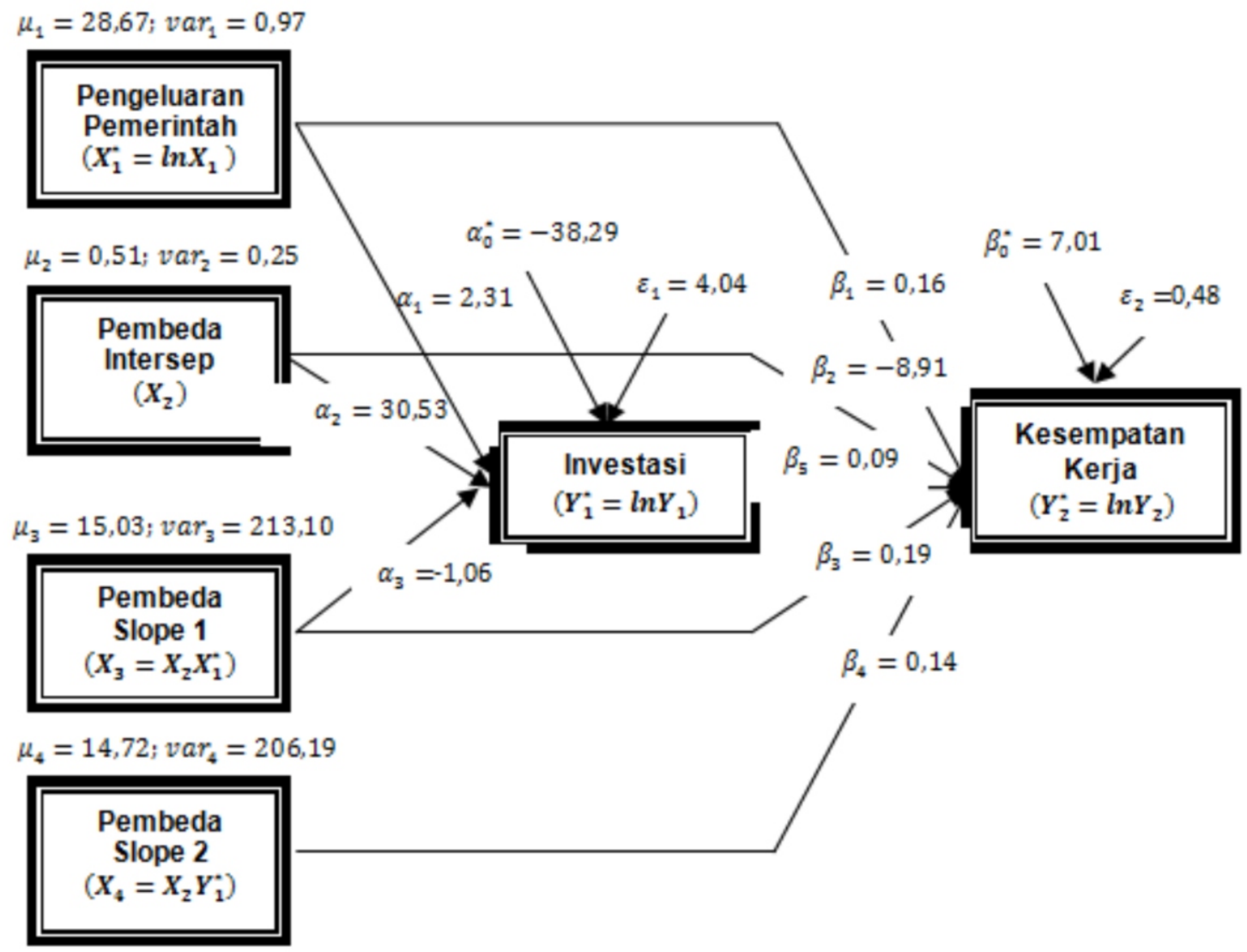

Gambar 4 Hasil Penelitian.

Sumber: Hasil Olah data dengan AMOS V21 
Tabel 6 Hasil Estimasi Parameter Hubungan antar Variable

\begin{tabular}{|c|c|c|c|c|c|c|c|}
\hline \multicolumn{2}{|c|}{ Variabel } & \multicolumn{6}{|c|}{ Estimasi Parameter } \\
\hline Endogen & Eksogen & Simbol & Nilai & S.E & C.R & $P$ & Sig, $\alpha(5 \%)$ \\
\hline $\begin{array}{c}\text { Investasi } \\
\left(Y_{1}^{*}\right)\end{array}$ & $\begin{array}{c}\text { Pengeluaran } \\
\text { Pemerintah } \\
\left(X_{1}^{*}\right) \\
\text { Dummy } \\
\left(X_{2}\right) \\
\text { Kontrol } \\
\left(X_{3}\right)\end{array}$ & $\begin{array}{l}\alpha_{1} \\
\alpha_{2} \\
\alpha_{3}\end{array}$ & $\begin{array}{c}2,31 \\
30,535 \\
-1,064\end{array}$ & $\begin{array}{l}0,134 \\
0,265 \\
0,009\end{array}$ & $\begin{array}{c}17,218 \\
115,25 \\
2 \\
- \\
117,35 \\
0\end{array}$ & $\begin{array}{l}* * * * \\
* * * \\
* * *\end{array}$ & $\begin{array}{l}\text { Sig } \\
\text { Sig } \\
\text { Sig }\end{array}$ \\
\hline $\begin{array}{c}\text { Kesempatan } \\
\text { Kerja } \\
\left(Y_{2}^{*}\right)\end{array}$ & $\begin{array}{c}\text { Pengeluaran } \\
\text { Pemerintah } \\
\left(X_{1}^{*}\right) \\
\text { Dummy } \\
\left(X_{2}\right) \\
\text { Kontrol1 } \\
\left(X_{3}\right) \\
\text { Kontrol2 } \\
\left(X_{4}\right) \\
\text { Investasi } \\
\left(Y_{1}^{*}\right)\end{array}$ & $\begin{array}{l}\beta_{1} \\
\beta_{2} \\
\beta_{3} \\
\beta_{4} \\
\beta_{5}\end{array}$ & $\begin{array}{l}0,163 \\
-8,911 \\
0,194 \\
0,138 \\
0,085\end{array}$ & $\begin{array}{l}0,070 \\
0,696 \\
0,024 \\
0,003 \\
0,023\end{array}$ & $\begin{array}{r}2,335 \\
-12,803 \\
8,006 \\
43,521 \\
3,771\end{array}$ & $\begin{array}{c}0,02 \\
0 \\
* * * \\
* * * \\
* * * \\
* * *\end{array}$ & $\begin{array}{l}\text { Sig } \\
\text { Sig } \\
\text { Sig } \\
\text { Sig } \\
\text { Sig }\end{array}$ \\
\hline
\end{tabular}

Sumber: Hasil Olah Data dengan AMOS V21.

6.PEMBAHASAN HASIL

\subsection{Pengaruh Pengeluaran Pemerintah terhadap Investasi di KBI dan di KTI.}

Berdasatkan Gambar 4 dan Tabel 6 tampak bahwa Pengaruh Pengeluaran Pemerintah terhadap Investasi di KBI adalah 2,31 dan signifikan, sedangkan di KTI adalah 1,25 dan signifikan. Artinya jika Pengeluaran Pemerintah dinaikkan sebesar 1 persen, maka akan diikuti dengan kenaikan Ivestasi (PMA dan PMDN) sebesar 2,31 persen di KBI dan 1,25 persen di KTI. Hal ini sesuai dengan teori Crawding In dimana salah satu tujuan dari peningkatan pengeluaran pemerintah (Hukum Wagner) adalah perbaikan berbagai infrastruktur Negara seperti fasilitas transportasi, sarana prasarana pendidikan dan kesehatan sehingga para

Page 10
Investor tertarik untuk menanamkan modalnya atau semakin meningkatkan penanaman modalnya.

\subsection{Pengaruh Investasi terhadap Kesempatan Kerja di KBI dan di KTI. \\ Pengaruh Investasi terhadap} Kesempatan Kerja di KBI adalah 0,09 dan signifikan, sedangkan di KTI adalah 0,23 dan signifikan. Artinya jika Investasi dinaikkan sebesar 1 persen pada kedua kawasan, maka akan diikuti dengan kenaikan Kesempatan Kerja sebesar 0,09 persen di KBI dan 0,23 persen di KTI. Hal ini sesuai dengan beberapa teori antara lain teori Lewis, teori Ranis-Fei dan teori Harrod-Domar tentang peningkatan Investasi akan berdampak pada peningkatan kesempatan kerja.

fe_manajemen@unmuh-kupang.ac.id 


\subsection{Pengaruh Pengeluaran Pemerintah terhadap Kesempatan Kerja di KBI dan di KTI. \\ Pengaruh Langsung}

Pengaruh Langsung Pengeluaran Pemerintah terhadap Kesempatan Kerja di KBI adalah 0,16 dan signifikan, sedangkan di KTI adalah 0,35 dan signifikan. Artinya jika Pengeluaran Pemerintah dinaikkan sebesar 1 persen, maka akan diikuti dengan kenaikan Kesempatan Kerja sebesar 0,16 persen di KBI dan 0,35 persen di KTI. Hal ini sesuai dengan teori dimana salah satu tujuan dari peningkatan pengeluaran pemerintah (teori Keynes) adalah mengatasi pengangguran atau meningkatkan kesempatan kerja antara lain penerimaan PNS, Polisi, Militer dan mendorong kesempatan kerja di swasta.

\section{Pengaruh Tidak Langsung}

Pengaruh Tidak Langsung Pengeluaran Pemerintah melalui Investasi terhadap Kesempatan Kerja di KBI adalah $0,21(2,31 \times 0,09)$ dan signifikan, sedangkan di KTI adalah $0,29(1,25 \times 0,23)$ dan signifikan. Artinya jika Pengeluaran Pemerintah dinaikkan sebesar 1 persen, maka akan diikuti dengan kenaikan Kesempatan Kerja sebesar 0,21 persen di KBI dan 0,29 persen di KTI. Hal ini sesuai dengan gabungan teori Crawding In dan teori Lewis, Ranis-Fei, dan teori HarrodDomar.

\section{Pengaruh Total}

Pengaruh Total Pengeluaran Pemerintah terhadap Kesempatan Kerja di KBI adalah $0,37(0,16+0,21)$ dan signifikan, sedangkan di KTI adalah 0,64 $(0,35+0,29)$ dan signifikan. Artinya jika Pengeluaran Pemerintah dinaikkan sebesar 1 persen, maka akan diikuti dengan kenaikan Kesempatan Kerja sebesar 0,37 persen di KBI dan 0,64 persen di KTI. Hal ini sesuai dengan bahwa salah satu tujuan dari peningkatan pengeluaran pemerintah adalah mengatasi pengangguran.
Perbedaan Pengaruh Pengeluaran Pemerintah terhadap Investasi, Pengeluaran Pemerintah terhadap Kesempatan Kerja dan Investasi terhadap Kesempatan Kerja di KBI dengan di KTI.

\section{Perbedaan Pengaruh Langsung}

Adapun perbedaan pengaruh langsung di KBI dengan di KTI; pengeluaran pemerintah terhadap investasi adalah $-1,06$ artinya pengaruh pengeluaran pemerintah terhadap investasi lebih besar di KBI daripada di KTI. Sementara perbedaan pengaruh pengeluaran pemerintah terhadap kesempatan kerja adalah 0,19 artinya pengaruh pengeluaran pemerintah terhadap kesempatan kerja lebih kecil di KBI daripada di KTI. Sedangkan perbedaan pengaruh investasi terhadap kesempatan kerja adalah 0,14 , artinya pengaruh investasi terhadap kesempatan kerja lebih kecil di KBI.

\section{Perbedaan Pengaruh Tidak langsung}

Perbedaan Pengaruh Tidak langsung di KBI dengan di KTI adalah 0,08 artinya pengaruh Pengeluaran Pemerintah terhadap Kesempatan Kerja melalui Investasi di KBI lebih kecil daripada di KTI.

\section{Perbedaan Pengaruh Total}

Perbedaan Pengaruh Total di KBI dengan di KTI adalah 0,27 artinya pengaruh Pengeluaran Pemerintah secara total terhadap Kesempatan Kerja di KBI lebih kecil daripada di KTI.

\section{KESIMPULAN DAN SARAN}

Berdasarkan pembahasan hasil, baik pengaruh langsung dan tidak langsung maupun pengaruh total hipotesis 1, 2, dan 3 semua terpenuhi. Adapun perbedaan pada hipotesis 4 ternyata hanya pengaruh pengeluaran pemerintah terhadap investasi yang lebih besar di KBI daripada di KTI, 
yang lainnya yakni pengaruh investasi terhadap kesempatan kerja, pengaruh pengeluaran pemerintah terhadap kesempatan kerja (langsung, tidak langsung, dan total) semuanya lebih besar di KTI daripada di KBI dengan perbedaan pengaruh sekitar dua kali lipat. Hal ini memberi pesan bahwa untuk pengeluaran pemerintah dengan porsi persentase yang sama, para investor lebih tertarik menanamkan modalnya di KBI daripada di KTI. Namun pengaruhnya terhadap kesempatan kerja, KTI lebih bergantung pada besarnya pengeluaran pemerintah daripada KBI. Atau dengan perkataan lain KBI lebih mandiri/lebih mapan daripada KTI.

Karena itu disarankan kepada pengambil kebijakan untuk lebih memperbesar porsi persentasi pengeluaran pemerintah yang dialokasikan di KTI agar para investor beralih perhatian ke kawasan ini sehingga pengaruhnya yang saat ini lebih besar secara berangsur angsur menciptakan kemandirian/kemapanan di KTI yakni kawasan yang memang tertinggal dalam pembangunan ekonomi.

\section{DAFTAR PUSTAKA}

Ahmadi et al. 2012. Uncertainty and Private Investment: Evidence from Iran. Journal of International Economics 12.

Baotai Wang. 2003. The Long-run Effects of Government Expenditure on Private Investment in Canada: An Emperical Investigation. European Journal of Economic and Political Studies, Ejeps-1(1), 2003.

Barro, Robert J. 2001. Human Capital and Growth, The American Economic Review, Vol. 91, No.2.

Berument, Hakan. Dogan, Nukhet and Tansel, Aysit. 2008. Macroeconomic Policy and Unemployment by Economic Activity: Evidence from Turkey. Forchungsinstitut zur Zukunft der Arbeit Institute for The Study of Labor.Discussion Paper No. 3461. April 2008.

BNP2TKI, 2013. Upah di 10 Negara Program Kerjasama $G$ to $G$ http://www.bnp2tki.go.id/beritamainmenu-231/8512-bnp2tki-lepas383-tki-formal-ke-9-negara-daneropa.html diakses pada tanggal 12 Des 2013.

Braga, Breno. Guillen, Diego and Thomson, Ben. 2013. Local Government Spending and the Labor-Market Multiplier: Evidence from Brazil. Department of Economics, University of Michigan, October 29, 2013.

Cavallo, Michele. 2005. Government Employment Expenditure and the Effects of Fiscal Policy Shocks. Federal Reserve Bank of San Francisco, Working Paper Series, September 2005.

Hakim, Abdul. 2004 . Ekonomi Pembangunan (Cetakan Kedua). Yogyakarta: EKONISIA Kampus Fakultas Ekonomi UII.

Harijono, Gatot Setio. 2010. Analisis Pengaruh Pengeluaran Pemerintah dan Investasi terhadap Kesempatan Kerja melalui Pertumbuhan Ekonomi. Jurnal Ekonomi Pembangunan (Online) Vol. 10, No. 1, 2010, ISSN 14116081.

Hendarmin. 2012. Pengaruh Belanja Modal Pemerintah Daerah dan Investasi Swasta terhadap Pertumbuhan Ekonomi, Kesempatan Kerja dan Kesejahteraan Masyarakat di 
Kabupaten/Kota Provinsi Kalimantan Barat. Jurnal UNTAN, Vol. 8, No. 3, Oktober 2012.

Karley, Noa. 2000. Government Investment, Growth and Employment in South Africa. Journal of Social Development in Africa (2000), 15, 1 .

Kiswanto Mohammad, 2013. Pengaruh Pengeluaran Pemerintah terhadap Keberpihakan Pembangunan (KP) melalui Investasi, Mutu Sumber Daya Manusia, Pertumbuhan Ekonomi dan Kesempatan Kerja di Provinsi Kalimantan Timur. Disertasi Doktor Fakultas Ekonomi dan Bisnis Universitas Hasanuddin Makassar.

Lin, 1994. Government Spending and Economic Growth. The Journal of Economic Analysis. Ahmadu Bello University. Year 1994, Vol. I, Issue II.

Liste, Janvier. Kolster, Jacob and Fundani, Nono Matondo. 2012. Chines Investments and Employment Creation in Algeria and Egypt. African Development Bank (AfDB). Economic Brief. 2012.

Mankiw, Gregory N. 2007. Principles of E c o n o m o c s. $3^{\text {rd }}$

Edition. Cengage Learning Asia Pte Ltd.

Mapita, Indra. 2012. Simulasi Pengeluaran Pemerintah dan Dampaknya terhadap Kinerja Ekonomi Makro: Suatu Model Computable General Equilibrium. QE Journal, Vol. 01, no.02-1

Nugroho. 2008. Evaluasi terhadap Faktor factor yang Mempengaruhi Investasi di Indonesia dan Implikasi Kebijakannya. Jurnal Riptek, Vol. 2, No. 1, Tahun 2008.
Olney, William W. 2013. A Race to The Bottom? Employment Protection and Foreign Direct Investment. Journal of International Economics 91 (2013).

Portal Nasional RI,2012. Penempatan TKI Keluar Negeri.

http://www.indonesia.go.id/en/ministries/mi nitres/ministry-of-manpower-and$\mathrm{t} \mathrm{r}$ a $\mathrm{n} \mathrm{s} \mathrm{m}$ i g r a t i o n / 497 ketenagakerjaan/12244-muhaiminpenempatan-tki-sektor-formalmeningkat-jadi-52-\%-tahun-2012 diakses pada tanggal 12 Des 2013

Prasetyia, Ferry .2011. Rekonstruksi Sistem Fiskal Nasional dalam Bingkai Kontitusi. Journal of Indonesian Applied Economics. Vol. 5, No. 2 Oktober 2011.

Rahardja Prathama, Manurung Mandala. 2004. Pengantar Ilmu Ekonomi (Mikroekonomi \& Makroekonomi) Edisi Ketiga. Jakarta: LP-FEUI.

Ramey, Valerie A. 2012. Government Spending and Private Activity. University of California, Sandiego and NBER. Januari 2012.

Richard,, Froyen T. 2002 . MacroeconomicsnTheorities And Policies (Seventh Edition). USA: Prentice Hall.

Rizvi, Syed Zia Abbas and Nishat, Mohammad. 2009. The Impact of Foreign Direct Investment on Employment Opportunities: Panel Data Analysis: Empirical Evidence from Pakistan, India and China. Institute of Business Management (IoBM), Karachi. Revised: December 10.2009. 
Sasana, Hadi. 2008. Analisis Faktor Factor yang Mempengaruhi Investasi Swasta di Jawa Tengah. Jurnal Ekonomi dan Perpajakan (Jejak) UNNES , Vol.1, No.1, September, 2008.

Sodik Jamzani dan Nuryadin Didi.2004. Investasi dan Pertumbuhan Ekonomi Regional (Studi Kasus pada 26 Provinsi di Indonesia, Pra dan Pasca Otonomi). Jurnal Ekonomi Pembangunan, Kajian Ekonomi Negara Berkembang.

Suindyah D, Sayeti. 2009. Pengaruh Investasi, Tenaga Kerja dan Pengeluaran Pemerintah terhadap Pertumbuhan Ekonomi di Provinsi Jawa Timur. Jombang: Ekuitas Universitas Darul 'Ulum

Sun'an Muammil \& Astuti Endang. 2008. Analisis Investasi, Pengeluaran Pemerintah dan Pertumbuhan Ekonomi Terhadap Kesempatan Kerja Di Provinsi Nusa Tenggara Barat. Jurnal Iqtishodunia, Vol. 1. No.1, Februari 2007.

Todaro, M.P., Smith S. C, 2006. Pembangunan Ekonomi (Edisi Kesembilan). (Drs. Haris Munandar, MA dan Puji A.L., SE, Pentj). Jakarta : rd PT. Gelora Aksara Pratama.

Wahyuningtyas, Agustina Endah, 2010. Analisis Pengaruh Pengeluaran Pemerintah dan Defisit Anggaran terhadap Investasi di Indonesia. Skripsi. Semarang: Fakultas Ekonomi Universitas Diponegoro.

Walterskirchen, Ewald, 1999. The Relationship between Growth, Employment and Unemployment in the EU; European Economist for an Alternative Economic Policy (tsernetwork), Workshop in
Barcelona, September 1999. 